\title{
INFLUENCE OF STRAIN RATE ON TENSILE STRENGTH OF WOVEN GEOTEXTILE IN THE SELECTED RANGE OF TEMPERATURE
}

\author{
SYLWIA STĘPIEŃ, ALOJZY SZYMAŃSKI \\ Warsaw University of Life Sciences - SGGW, Faculty of Civil and Environmental Engineering, \\ ul. Nowoursynowska 159, 02-776 Warszawa, Poland, \\ e-mail: sylwia_stepien@sggw.pl,alojzy_szymanski@sggw.pl
}

\begin{abstract}
Investigation of geosynthetics behaviour has been carried out for many years. Before using geosynthetics in practice, the standard laboratory tests had been carried out to determine basic mechanical parameters. In order to examine the tensile strength of the sample which extends at a constant strain rate, one should measure the value of the tensile force and strain. Note that geosynthetics work under different conditions of stretching and temperatures, which significantly reduce the strength of these materials. The paper presents results of the tensile test of geotextile at different strain rates and temperatures from $20{ }^{\circ} \mathrm{C}$ to $100{ }^{\circ} \mathrm{C}$. The aim of this study was to determine the effect of temperature and strain rate on tensile strength and strain of the woven geotextile. The article presents the method of investigation and the results. The data obtained allowed us to assess the parameters of material which should be considered in the design of the load-bearing structures that work at temperatures up to $100{ }^{\circ} \mathrm{C}$.
\end{abstract}

Key words: geotextile, tensile strength, strain rate, temperature

\section{INTRODUCTION}

Over the last three decades there has been considerable development of geotechnics, concerning the methods and procedures which improve soft subsoil [6]. The common belief is that such a subsoil, due to insufficient bearing capacity and high compressibility, causes many difficulties in direct foundation of a building [9]. Geosynthetics that reinforce the subsoil can play a supporting role as they not only increase the load-bearing capacity but at the same time they reduce deformations [4]. However, the average temperature varies depending on location and season [2]. The temperature and strain rate effect on tensile strength need further investigation. Tremendous progress in the development of geotechnics is assigned to geosynthetics. Thanks to various forms they can serve many functions, such as separation of layers, protection against erosion of soil surface, drainage and filtration, sealing, soil reinforcement and structural layers of paving and construction of retaining structures [5], [7]. The choice of reinforcement material is not simple. Designer's experience and the knowledge of the environment are very useful here, as well as laboratory tests carried out taking into account the functions that the material plays in the structure.

\section{DESCRIPTION OF LABORATORY EQUIPMENT}

The purpose of the study was to determine the effect of the temperature on tensile strength and strain woven geotextile. The experiment was carried out according to the "PN-EN ISO 10319:2010 Geosynthetics - Wide-width tensile test" standard. Measurements of tensile strength and strain of woven geotextile were performed using equipment at SGGW Water Centre.

Tests were conducted using a tensile testing machine with a maximum power of $75 \mathrm{kN}$. This device allowed performing the test at temperatures from $-60{ }^{\circ} \mathrm{C}$ to $+280{ }^{\circ} \mathrm{C}$. Negative temperatures were obtained by liquid nitrogen and the positive temperatures by electric heater.

The tensile testing machine (Fig. 1) includes:

1 - Video extensometer,

2 - Load frame,

3 - Mechanical jaws, 

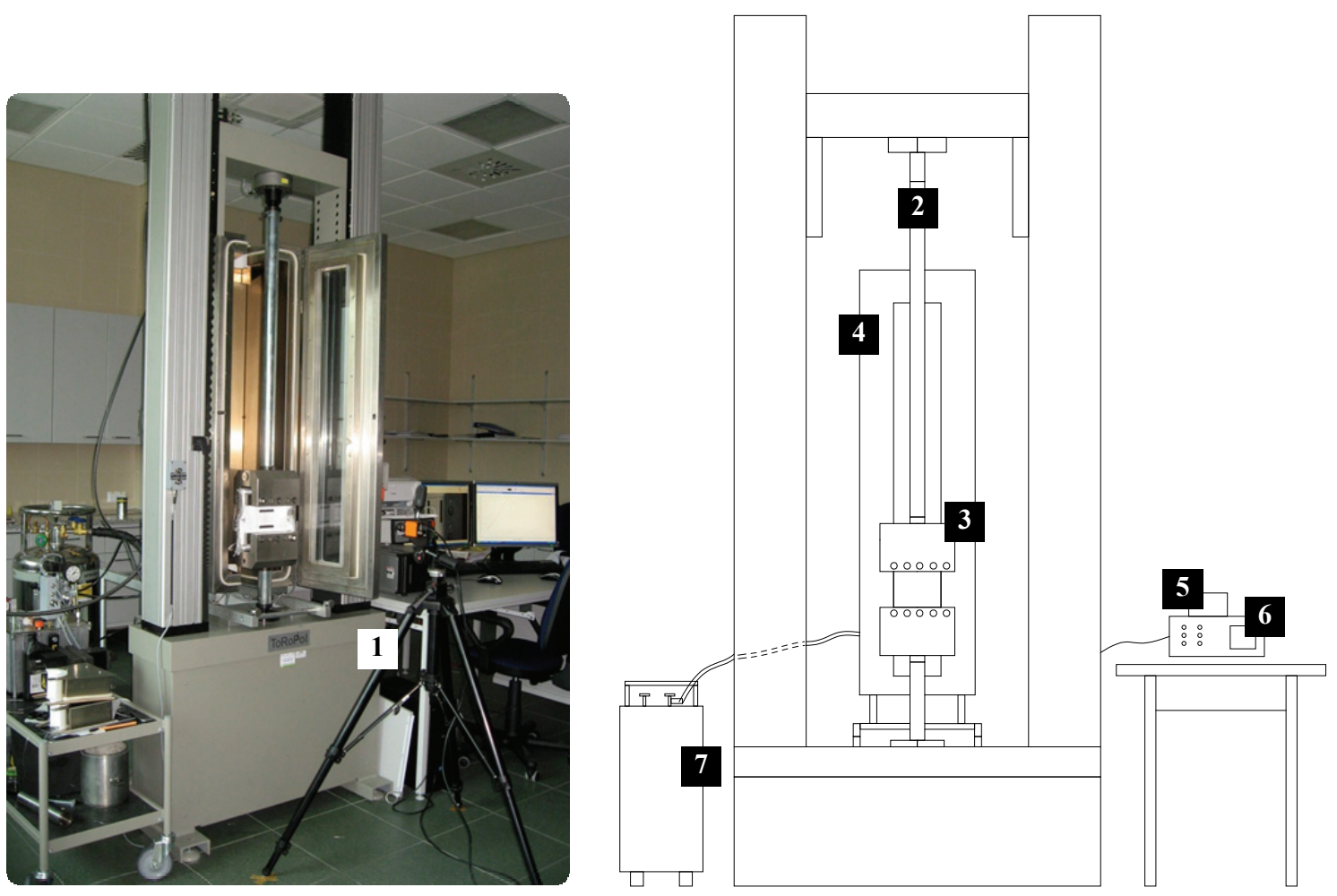

Fig. 1. Laboratory equipment for tensile test

4 - Climatic chamber,

5 - Tensile testing and climatic chamber driver,

6 - Computer recording system,

7 - Cylinder with liquid nitrogen.

\section{MATERIAL AND SAMPLE PREPARATION}

The aim of the test was to determine the tensile strength and strain at maximum load. The change of the length of the material was measured with video extensometer and was presented as the percentage of the total length of the sample. The video device followed the movement of the two reference points that were marked on the sample axis of symmetry and spaced by $60 \mathrm{~mm}$. A test sample was mounted across the width of the mechanical jaws of the machine, which operated at constant strain rate of $20 \%$ per minute until the material broke. In the method described, the width of the sample was greater than the length, because some geotextiles had a tendency to contract under load. The greater width reduced the contraction effect of such fabrics and reflected the material behavior in the field. The sample of $200 \mathrm{~mm}$ in width and $100 \mathrm{~mm}$ in length was used. It was recommended to test minimum 5 samples in the longitudinal direc- tion and the transverse direction [8]. The geosynthetics should be tested before being used as a structural element. To carry out the test correctly one should take into account the type of construction and environment where the geosynthetic works [5]. When geotextile serves as reinforcement strength deformation and durability should be examined. The properties of geotextile are changed under influence of atmospheric factors such as UV light, elevated or reduced temperature and water content, etc. [1].

The geotextile tested in the laboratory was made of high polyester fibers arranged in the longitudinal direction $(T=200 \mathrm{kN} / \mathrm{m}, \varepsilon=10 \%)$ and polyamide fibers in the transverse direction $(T=45 \mathrm{kN} / \mathrm{m}, \varepsilon=20 \%)$. This material resisted high tensile loads with slight strain and is applied primarily in the reinforcement of earthen structures. It is also justified to use the geotextile for construction of embankments, hydraulic engineering structures, the construction of water channels, breakwaters, etc.

\section{TEST RESULTS}

A series of tensile tests with the polyester woven geotextile at different temperatures and strain rates were conducted. The test temperatures varied from 
20 to $80{ }^{\circ} \mathrm{C}$. Strain rate was $0.02 \mathrm{~mm}$ per minute and $20 \mathrm{~mm}$ per minute. Temperature inside the chamber, tensile load and strain were recorded using an automatic data acquisition system. All tests were carried out using specimens from the same roll and performed using the same instrumentation and specimen preparation procedures. Tests were conducted in the machine direction (MD) of the geotextile specimens. Five test specimens were used for each temperature tested. The tensile test results for $20{ }^{\circ} \mathrm{C}$ and $20 \mathrm{~mm}$ per minute strain rate test conditions are shown in Fig. 2. A typical double-S curve was observed for all temperatures tested. The ultimate tensile strength versus temperature was analyzed and plotted in Fig. 3. As shown in the figure, the ultimate tensile strengths decreased nearly linearly when the test temperature increased to $100{ }^{\circ} \mathrm{C}$ at $20 \mathrm{~mm}$ per minute strain rate. Note that tensile strength decreased more at $0.02 \mathrm{~mm}$ per minute strain rate. Figure 4 shows that the tensile strain at maximum load was constant till $60^{\circ} \mathrm{C}$. The strain at the breakage moment at a temperature of $80{ }^{\circ} \mathrm{C}$ was different with other test results. Probably the reason for the sudden increase of strain at $80^{\circ} \mathrm{C}$ was that the glass transition temperature of PES fibres was near $80^{\circ} \mathrm{C}[3]$.

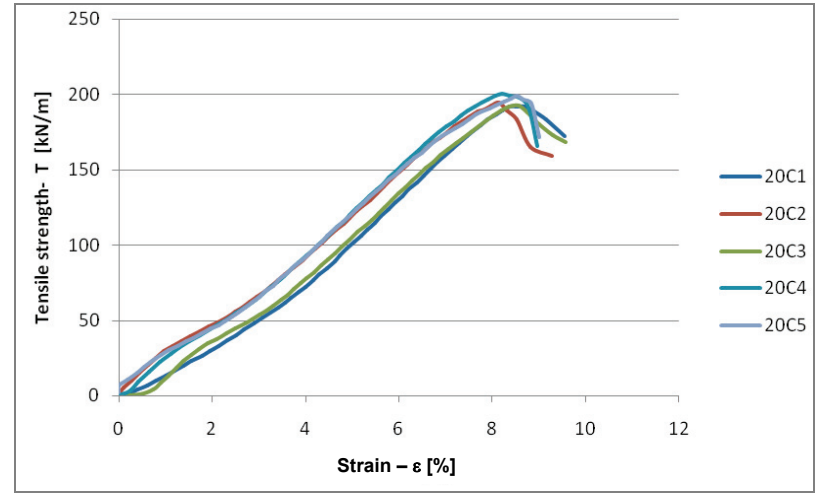

Fig. 2. Strain and load per unit width relationship for woven geotextile samples tested at $20{ }^{\circ} \mathrm{C}$ and $20 \mathrm{~mm} / \mathrm{min}$ strain rate

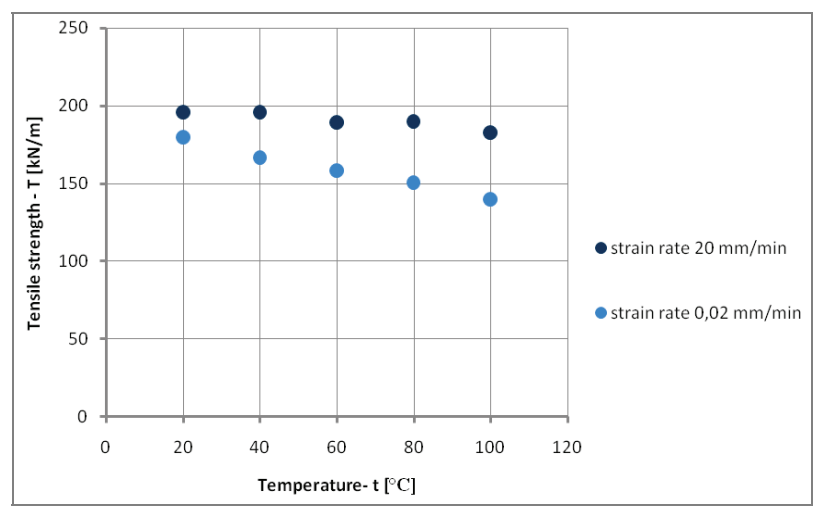

Fig. 3. Average value of maximum tensile strength of woven geotextile at $20 \mathrm{~mm} / \mathrm{min}$ and $0.02 \mathrm{~mm} / \mathrm{min}$ strain rate and temperature from 20 to $100{ }^{\circ} \mathrm{C}$

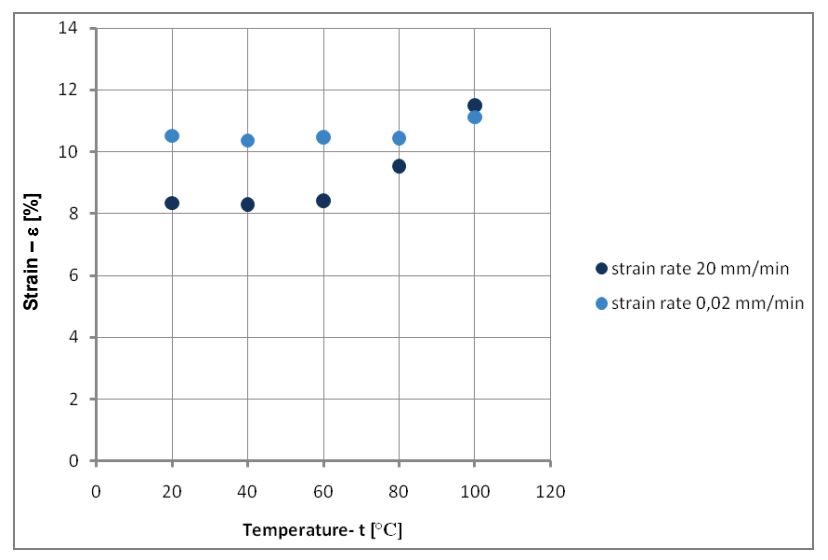

Fig. 4. Average value of tensile strain of woven geotextile at $20 \mathrm{~mm} / \mathrm{min}$ and $0.02 \mathrm{~mm} / \mathrm{min}$ strain rate and temperature from 20 to $100{ }^{\circ} \mathrm{C}$

In Table 1 it can be noticed that geotextile that works in the construction at a temperature of about $20{ }^{\circ} \mathrm{C}$, and stretches slowly, as it was designed in the laboratory, can lose up to $10 \%$ of its strength. In Table 2, the geosynthetic that works at elevated temperatures (up to $100{ }^{\circ} \mathrm{C}$ and extends slower at $0.02 \mathrm{~mm}$ per minute strain rate) can lose up to $25 \%$ of its tensile strength.

Table 1. Laboratory test results for woven geotextile samples tested at $20^{\circ} \mathrm{C}$

\begin{tabular}{|c|c|c|c|c|}
\hline \multirow{2}{*}{ No. } & \multicolumn{2}{|c|}{ Strain rate $20 \mathrm{~mm} / \mathrm{min}$} & \multicolumn{2}{c|}{ Strain rate $0.02 \mathrm{~mm} / \mathrm{min}$} \\
\cline { 2 - 5 } & $T_{\max }[\mathrm{kN} / \mathrm{m}]$ & $\varepsilon[\%]$ & $T_{\max }[\mathrm{kN} / \mathrm{m}]$ & $\varepsilon[\%]$ \\
\hline 1 & 191.94 & 8.38 & 180.92 & 10.35 \\
\hline 2 & 194.62 & 8.15 & 182.97 & 11.26 \\
\hline 3 & 192.83 & 8.56 & 178.54 & 10.46 \\
\hline 4 & 201.44 & 8.79 & 178.84 & 10.46 \\
\hline 5 & 199.18 & 8.53 & 176.83 & 10.07 \\
\hline$\overline{\boldsymbol{x}}$ & $\mathbf{1 9 6 . 0 0}$ & $\mathbf{8 . 4 8}$ & $\mathbf{1 7 9 . 6 2}$ & $\mathbf{1 0 . 5 2}$ \\
\hline$s$ & 4.13 & 0.24 & 2.37 & 0.38 \\
\hline$V$ & 2.10 & 2.83 & 1.32 & 3.61 \\
\hline
\end{tabular}

Table 2. Laboratory test results for woven geotextile samples tested at $100{ }^{\circ} \mathrm{C}$

\begin{tabular}{|c|c|c|c|c|}
\hline \multirow{2}{*}{ No. } & \multicolumn{2}{|c|}{ Strain rate $20 \mathrm{~mm} / \mathrm{min}$} & \multicolumn{2}{c|}{ Strain rate $0.02 \mathrm{~mm} / \mathrm{min}$} \\
\cline { 2 - 5 } & $T_{\max }[\mathrm{kN} / \mathrm{m}]$ & $\varepsilon[\%]$ & $T_{\max }[\mathrm{kN} / \mathrm{m}]$ & $\varepsilon[\%]$ \\
\hline 1 & 188.80 & 12.47 & 135.32 & 11.12 \\
\hline 2 & 181.77 & 10.63 & 143.61 & 10.61 \\
\hline 3 & 176.12 & 12.27 & 137.93 & 11.14 \\
\hline 4 & 179.55 & 11.01 & 142.04 & 11.25 \\
\hline 5 & 186.56 & 11.11 & 140.16 & 11.46 \\
\hline $\bar{x}$ & $\mathbf{1 8 2 . 5 6}$ & $\mathbf{1 1 . 5 0}$ & $\mathbf{1 3 9 . 8 1}$ & $\mathbf{1 1 . 1 2}$ \\
\hline$s$ & 5.15 & 0.82 & 3.39 & 0.31 \\
\hline$V$ & 2.82 & 7.13 & 2.42 & 2.79 \\
\hline
\end{tabular}




\section{CONCLUSIONS}

Selection of materials for the layers of geosynthetic reinforcement is essential to ensure the efficient operation and durability of the structure [2]. The research of the tensile strength using a widewidth strip geotextile has shown that a decrease in tensile strength was about $7 \%$ and an increase of the strain was $12.5 \%$ in the longitudinal direction. According to the standard PN-EN ISO 10319:2010 sample should be extended at a constant strain rate. It needs to be noted that geosynthetic works in different stretching conditions and varied temperatures, which reduces the strength and deformability of these materials substantially. In summary, selection of geosynthetics for engineering constructions should be made taking the reduction of strength due to temperature and strain rate. The effect of a significant increase of deformation is undoubtedly important for the design of reinforcement in landfills, where temperatures reach $80{ }^{\circ} \mathrm{C}$ [10]. It is important to define reduction factors, for specific geosynthetics, based on conditions as close as possible to those of the sites where they are to be used [12]. Finally, this study provides a better understanding of the durability of polyester woven geotextiles that are exposed to climatic agents and their behaviour under different stretching conditions.

\section{REFERENCES}

[1] CAStro C.A.C., GuimarãEs M.G.A., LoPEs M.L.C., UrashimA D.C., Durability of a Polypropylene Woven Geotextile under
Climatic and Chemical Agents, 10th International Conference on Geosynthetics, 21-25 September 2014, Berlin, 2014.

[2] Chiwan H., Yen-Chen T., Tensile creep behavior of a PVC coated polyester geogrid at different temperatures, Journal of GeoEngineering, 2008, Vol. 3(3), 113-119.

[3] CHODYŃSKI A., Dobór geotekstyliów, Międzynarodowa Konferencja Naukowo-Techniczna: „Geotekstylia w budowie i remontach dróg", 27-28 stycznia 1994, Ustroń 1994.

[4] CHODYŃsKi A., Trwałości surowców stosowanych $w$ geosyntetykach. VIII Konferencja Naukowo-Techniczna: „Szkoła metod projektowania obiektów inżynierskich z zastosowaniem geosyntetyków”, Ustroń, 3-5 kwietnia 2002.

[5] KAZIMIEROwICZ-FranKowsKa K., Zasady modelowania pracy geosyntetycznego zbrojenia wykorzystywanego do wzmacniania konstrukcji dróg, Inżynieria Morska i Geotechnika, 2013, Vol. 1, 43-51.

[6] KŁosiŃSKI B., Zastosowanie krajowych geotekstyliów w budownictwie komunikacyjnym, Inżynieria i Budownictwo, 1996, Vol. 11, 628-630.

[7] Koerner R.M., Designing with Geosynthetics, 4th Edition, Upper Saddle River: Prentice Hall 1999.

[8] PN-EN ISO 10319 (2010). Geosyntetyki - Badanie wytrzymałości na rozciaganie metoda szerokich próbek.

[9] S̨̨KOWSKi J., Wykorzystanie geosyntetyków do wzmocnienia stabego podłoża oraz stabilizacji skarp nasypów $i$ wykopów. Techniczne, ekonomiczne $i$ organizacyjne aspekty gospodarki odpadami, V Jubileuszowe Międzynarodowe Forum Gospodarki Odpadami, Poznań, 18-21 maja 2003.

[10] SuchowsKa-Kisielewicz M., Skład chemiczny odcieków $z$ odpadów przed i po mechaniczno-biologicznym przetworzeniu, Rozprawa doktorska, Uniwersytet Zielonogórski, Zielona Góra, 2008.

[11] Zornberg J.G., Asce M., Byler B.R., Knudsen W.J., Creep of Geotextiles Using Time-Temperature Superposition Methods, Journal of Geotechnical and Geoenvironmental Engineering, 2004, Vol. 130(11), 1158-1168, DOI: 10.1061/(ASCE)1090-0241(2004)130:11(1158). 